\title{
Raised Gastric Hydrochloric Acid Levels in Gnetum Africana Consump- tion but Low Levels in Talinum Trangulare Admixture
}

\author{
E.O. Jimmy ${ }^{1, *}$ and U. R. German ${ }^{2}$
}

Department of Physiology, Faculty of Basic Medical Sciences, University Of Uyo, Akwa Ibom State, Nigeria

\begin{abstract}
Altered gastric physiology in albino rats fed with aqueous extract of Gnetum africana and Talinum triangulare (water leaf) was investigated in gastric hydrochloric acid secretion for the period of 7, 21 and 28 days. The results of mean acid output in the test group that received Gnetum Africana extract alone was significantly increased $\mathrm{P}<0.05$ on day 7 as compared with control group which was same on days 21 and 28. However, the mean acid output was significantly decreased, P $<0.05$ when compared with control on day 7 and 21 respectively. In the test group that received Gnetum africana and Talinum triangulare extract there was significant decrease in gastric Hydrochloric acid after days 7 and 21 and more significantly decreased in 28 days, $\mathrm{P}<0.01$ as compared with control. But there was decrease mean hydrochloric acid output in Gnetum africana and Talinum triangulare mixture than Gnetum africana alone. It is concluded that increase consumption of Gnetum africana has the tendency of increasing gastric Hydrochloric acid secretion and likely associated pathology; gastric ulcer.
\end{abstract}

Keywords: Gnetum Africana, Talinum Traingulare, Gastric secretion.

\section{INTRODUCTION}

Gnetum africana belongs to the family Gnetacea and order Gnetales, [1] The leaf and the seeds are used in the treatment of enlarged spleen, sore throat, as anaesthsia in labor pains, as fungicides, and in the management of excessive urination in infantile, diabetes, [2]. But Gnetum africana leaves are the highly and widely consumed in Nigeria as favourite leaves in soup making particularly in the South South and South East Zones it delicious as taste with little or no soup making ingredients e.g fish or meat. In the South South Akwa Ibom it is called Afang while in the South East Zone of Nigeria is called Ukasi. The vegetable is also gaining its usage in Cameroon, Gabon, Congo and Angola, [3], but it is not grown in the North and South West of Nigeria. Apart from its use in making soup it is also used as local salad mixed with palm oil but this aspect is not widely used and the raw consumption may be toxic Gnetum africana contains carbohydrate, lipid proteins and rich in phytochemical constituents of alkaloid, saponin, flavonoid, anthocyanide, and hydrocyanide, sterols tannin of all the constituents alkaloid is most available. Talinum triagulare also known as water leaf is a herbaceous plant widely grown in the tropics. It is used in cooking pumpkin leaves and Gnetum africana soup as softener. It is medicinally used to reduce high fever and as laxative particularly in children. It is also used in the management of cardiovascular diseases e.g stroke and in Obesity, [4]. It contains calcium, potassium, magnesium, vitamins and proteins, [5]. The present study was prompted, based on the high consumption of Gnetum africana which some families cannot do without it on the

*Address correspondence to this author at the Department of Physiology, Faculty of Basic Medical Sciences, University of Uyo, Akwa Ibom State, Nigeria; Tel: 08069543646; E-mail: medstedrecheo@yahoo.com daily basis and in the era of many foods likely to evoke gastric acid the investigation becomes very imperative. Though, gastric hydrochloric acid secretion is meant for protein metabolism and protection, high secretion is incriminated in gastric ulcer [6]. The gastric mucosa secretes about 1.51 of gastric juice daily [7]. The constituents include, hydrochloric acid, pepsinogen, intrinsic factor, mucus, electrolytes e.g sodium, potassium, bicarbonate. It also contains enzymes e.g gastric amylase, lipase. Others are carbonic anhydrase, rennin, urease and gelatinase [8]. The basic factors that stimulate gastric secretion are acetylcholine, gastrin and histamine. But the gastrin and histamine pathway which is hormonal mechanism gives copious secretion of hydrochloric acid mediated to via enterochromatoffin like cells, histidine decarboxylase and $\mathrm{H} 2$ receptors [9]. Gastric secretion is also regulated by nervous mechanism. The nervous system can stimulate release of positive hydrogen ion to form $\mathrm{HCl}$ as with acetylcholine secreted by the nerve ending fibre, innervating the parietal cells and the M3 receptor binding.

The corresponding effect which include increase cytosolic calcium, stimulation of protein kinase and subsequent activation of $\mathrm{H} / \mathrm{K}$ ATpase and $\mathrm{HCl}$ secretion.

\section{MATERIALS AND METHODS}

Animals: A total of twenty seven (27) albino rats were used in the study. The animals were fed with growers (pellets) and water and maintained in a well ventilated, Faculty of Pharmacy animal house throughout the period of study. The twenty seven albino rats were divided into three groups with nine animals in each group. Collection and Extraction of Gnetum Africana and talinum triangulare The Gnetum africana were purchased from an open market and identified by the Department of Pharmacognosy Natural Medicine, 
Faculty of Pharmacy, University of Uyo. The method of Trease and Evans [10] was used for the extraction. The leaves were washed dried and pounded to obtain 200g of powdered, Gnetum africana. The $200 \mathrm{~g}$ was dissolved in $400 \mathrm{ml}$ of distilled water and allowed to stand for 24 hours and was macerated and filtered to obtain the aqueous extract. The aqueous extract was concentrated by evaporating to dryness at $40^{\circ} \mathrm{C}$ in a water bath and $22.1 \mathrm{~g}$ final extract was obtained. The quantity of final extract depends on the quantity of leaves used. ACUTE TOXICITY TEST (LD50) The method of [11] used a total of fifteen (15) mice was used and divided into three groups. The first group was given $3000 \mathrm{mg} / \mathrm{kg}$ of extractintraperitonally. The second group had $4000 \mathrm{mg} / \mathrm{kg}$ dosage of the extract and the was given $5000 \mathrm{mg} / \mathrm{kg}$. In all the groups there was no death recorded in animals which indicated, non toxicity of the plants; Gnetum africana. Same procedure was done for Talinum triagulare and no death recorded. Administration of Gnetum africana and Talinum triangulare Gnetum africana extract $1500 \mathrm{mg} / \mathrm{kg}$ of Gnetum africana extract was dissolved in $10 \mathrm{ml}$ of distilled water and given to the first group of nine albino rats orally using canula by-passing the oesophagus into the stomach, [12]. In the second group also nine albino rats were administered $1500 \mathrm{mg} / \mathrm{kg}$ Gnetum africana and same dosage of Talinum triangulare extract. The control group of nine albino rats was given $10 \mathrm{ml}$ of distilled water. Gastric Secretion Test (Titrable acidity) [13] The rats were anasthe sized with chloroform weekly 7, 21 and 28 days. The stomachs were removed and the end near the duodenum cut and the stomach contents squeezed to obtain the secretion. $5 \mathrm{ml}$ of distilled water was added to the volume obtained and titrated against $0.02 \mathrm{M}$ NaoH using two drops of phenol red. The results obtained were recorded as titrable acidity for 7,21 , and 28 days.

\section{RESULTS}

The results showed significant difference in mean acid output between group 1 and group 3 on day 7, $\mathrm{P}<0.05,18.67$ \pm 0.88 and $9.33 \pm 0.88$, it was also significantly different between group 2 and group $3 \mathrm{P}<0.019 .33 \pm 0.33$ and 9.33 \pm 0.88 , Tables, 1, 2 and 3 . On day 21 the mean acid output was significantly different between group 1 and group $3, \mathrm{P}<$
$0.01,18.60 \pm 0.67$ and $16.00 \pm 0.58$ and also significantly different between group 2 and group 3, $9.33 \pm 0.88$ and $16.00 \pm 0.58 \mathrm{P}<0.05$, tables 1,2 and 3 . The mean acid output on day 28 showed a significant difference between group 1 and group $3 \mathrm{P}<0.05,22.00 \pm 0.58$ and $8.67 \pm 0.88$ and between group 2 and group $3, \mathrm{P}<0.05,16.00 \pm 0.58$ and $8.67 \pm$ 0.88 Tables $\mathbf{1}, \mathbf{2}, \mathbf{3}$.

\section{DISCUSSION}

The study had shown the effects of Gnetum africana on the gastric physiology based on the period of usages. The Gnetum africana extract increased acid output on day 7 than its combination with Talinum triagulare with a highly reduced acid secretion. The implications are many, first it shows that Gnetum africana is a stimulant to gastric, and therefore the consumption of it will surely increase gastric acid secretion. Secondly, Gnetum africana is widely consumed by a very large population indicating that such consumption without Talinum triangulare is liable to high gastric acid secretion and the tendency of gastric ulcer. There is no report of gastric secretion in Gnetum africana and this happens to be the first documentation of inducement of high gastric acid secretion in Gnetum africana consumption. The report implies that there are many other foods that are saliently increasing physiologic distortions in the body but are largely consumed by many. Foods that are not tasty and mostly not appealing to many are not often widely consumed affirming the adage that what kills are often sweet. But what should be a stimulant in Gnetum africana to induce gastric acid secretion is rather a worry. However, Gnetum africana has about $15.05 \%$ of protein as one of the contents and protein diet is the major cause of gastrin release from the stomach antrum. Gastrin is a gastric hormone which when its receptors bind to the enterochromatoffin-like cells rat release histamine. Histamine is produced in the presence of histidine carboxylase as metabolic enzyme. The formation of histamine leads to it binding to $\mathrm{H} 2$ receptor on the parietal cells and subsequent release of $\mathrm{HCl}$. The gastrin histamine pathway is very effective in copious acid secretion than any other pathway. The reduction in mean acid output in Gnetum africana and Talinum triangulare combination indicated the neutralizing effect of the latter on Gnetum africana. The effect of

Table 1. Effects of Gnetum africana on Gastric Secretion

\begin{tabular}{|c|c|c|c|}
\hline \multirow{2}{*}{ No. of Rats } & Day 7 & Day 21 & Day 28 \\
\cline { 2 - 4 } & Titrable Acidity (mmol/L) & Titrable Acidity (mmol/L) & Titrable Acidity (mmol/L) \\
\hline \hline 1 & 3.20 & - & - \\
\hline 2 & 14.0 & - & - \\
\hline 3 & 20.0 & - & - \\
\hline 4 & - & 22.0 & - \\
\hline 5 & - & 16.0 & - \\
\hline 6 & - & 18.0 & 24.0 \\
\hline 7 & - & - & 18.0 \\
\hline 8 & - & - & 24.0 \\
\hline 9 & - & - & \\
\hline
\end{tabular}


Table 2. Effects of Gnetum africana and Talinum triangulare on Gastric Secretion

\begin{tabular}{|c|c|c|c|}
\hline \multirow{2}{*}{ No. of Rats } & Day 7 & Day 21 & Day 28 \\
\cline { 2 - 4 } & Titrable Acidity (mmol/L) & Titrable Acidity (mmol/L) & Titrable Acidity (mmol/L) \\
\hline \hline 1 & 8.0 & - & - \\
\hline 2 & 12.0 & - & - \\
\hline 3 & 8.0 & - & - \\
\hline 4 & - & 12.0 & - \\
\hline 5 & - & 16.0 & - \\
\hline 6 & - & 12.0 & 16.0 \\
\hline 7 & - & - & 18.0 \\
\hline 8 & - & - & 14.0 \\
\hline 9
\end{tabular}

Table 3. Gastric Secretion in Control Group

\begin{tabular}{|c|c|c|c|}
\hline \multirow{2}{*}{ No. of Rats } & Day 7 & Day 21 & Day 28 \\
\hline & Titrable Acidity (mmol/L) & Titrable Acidity (mmol/L) & Titrable Acidity (mmol/L) \\
\hline 1 & 10.0 & - & - \\
\hline 2 & 6.0 & - & - \\
\hline 3 & 8.0 & - & - \\
\hline 4 & - & 12.0 & - \\
\hline 5 & - & 10.0 & - \\
\hline 6 & - & 6.0 & - \\
\hline 7 & - & - & 6.0 \\
\hline 8 & - & - & 12.0 \\
\hline 9 & - & - & 8.0 \\
\hline
\end{tabular}

The titrable acidity was obtained using the following Silverton formular: Titrable acidity $=\underline{0.02 \mathrm{M} \mathrm{NaoH} . \mathrm{x}}$

Where

$\begin{array}{lll}\mathrm{X} & = & \text { Titre (titrated volume) } \\ \mathrm{Y} & = & \text { Original volume of the secretion obtained from the stomach }\end{array}$

Talinum triangulare is therefore inhibitory which implied such inhibition on the receptor on the enterochromatoffin like-cells (ECl), and that of $\mathrm{H} 2$ receptor on the parietal cells for the actual reduction of the gastric $\mathrm{Hcl}$ [14]. This means that Talinum triangulare may be used as antacid and as anticlcerogenic therapy in the form of $\mathrm{H} 2$ inhibitor drug gastric ulcer in treatment. The increase in acid put was periodic in the study i.e as the number of the days of usage increased the acid output also increased. This implies that the pathologic effects of the Gnetum africana is dependent on the period of usage. However, there are cases of achlorhydria [15], a situation of less or no gastric acid secretion which often spelt on the dysfunction of the parietal cells. It is quite likely that the use of low dosages of Gnetum africana may be useful in making available gastric $\mathrm{HCl}$ for protein metabolism which is impaired in achlorhydria. However, the status of parietal cells cum the effect of Gnetum africana was not investigated in the study. Talinum triangulaer (water leaf) is used as laxative and in pyrexia locally, which requires its orthodox documentation for clinical usage. Exploration of medical constitution of foods available in our environment as plants will go along way in bringing great relief of burden associated with ineffective and substandard drugs in our society. The study therefore recommends minimal consumption of Gnetum africana which with observed increase in weights of the rats in our study could boost nutritional status of the malnourished, especially children.

\section{CONFLICT OF INTEREST}

The authors confirm that this article content has no conflicts of interest.

\section{ACKNOWLEDGEMENTS}

None declared.

\section{REFERENCES} versity Press1981; pp. 286-8. 
[2] Smith PF. Uses of Nigerian leafy vegetables for diet modification: sodium and potassium. Nig j Nutr Sci 1983; 4: 21-7.

[3] Eyo E, Abel U. Chemical composition of G. africana leaves. Nig J Nutr Sci 1983; 4: 52-7.

[4] Guyton AC, Hall JE. In textbook of Medical Physiology. 11th ed. USA: Elsvier Saunders 2006.

[5] Ifon ET, Bassir O. The nutritional values of some Nigerian leafy green vegetables, Part 1: Vitamin, Toxicant and Mineral Contents. Food Chem 1979; 4: 263-7.

[6] Oyebola DO. In Essential Physiology for students of Medicine dentistry., Pharmacy and related disciplines. Vol. 1, Nigeria: Nihort Press, Ibadan 2002.

[7] Tripathi KD. In Essentials of Medical Pharmacology, 6th ed. New Delhi: Jp Medical Pub 2008.

[8] Semulingam K, Sembulingam S. In Essentials of Medical Physiology, $5^{\text {th }}$ ed. New Dehli: Jaypee Digital 2010.
[9] Kazuharu F, Takeshi A, Eiji N, et al. Crucial role of histamine for regulation of gastric acid secretion ascertained by histidine decarboxylase. J Pharmacol Exp Ther 2003; 307: 311-38.

[10] Trease, Evans WC. In Trease and Evans textbook of Pharmacognosy. USA: Saunders 1996.

[11] Lorke D. A new approach to practical acute toxicity testing. Arch Toxicol 1983; 54: 275-87.

[12] Robert A. Cytoprotection by Prostaglandins. Gastroenterol 1979; 77(4) 761-7.

[13] Silverton RE, Barker FS. In introduction to Medical Laboratory Technology. London: Butterworths 1985.

[14] Bertram G. In Basic and Clinical Pharmacology, $9^{\text {th }}$ ed, Newyork, Chicago, Sanfrancisco. London: McGraw Hill 2004.

[15] Bell, G H, Smith D S, \& Paterson C.R: In a text book of Pysiology, $10^{\text {th }}$ ed. Churchill Livingstone: Longman group limited 1980.

Received: May 02, 2012

Revised: July 22, 2012

Accepted: July 28, 2012

(C) Jimmy and German; Licensee Bentham Open.

This is an open access article licensed under the terms of the Creative Commons Attribution Non-Commercial License (http://creativecommons.org/licenses/by-nc/3.0/) which permits unrestricted, non-commercial use, distribution and reproduction in any medium, provided the work is properly cited. 